\title{
PENGARUH KNOWLEDGE MANAGEMENT TERHADAP SUSTAINABLE LIVELIHOOD
}

\author{
Ahmad Taufiq Soepardy ${ }^{1}$ \\ ${ }^{1}$ Program Studi Akuntansi, Fakultas Ekonomi, Universitas Nahdlatul Ulama Sulawesi Tenggara \\ Kendari, Indonesia \\ e-mail: ahmadtaufiq8899@gmail.com
}

\begin{abstract}
ABSTRAK
Penelitian ini bertujuan untuk menguji dan menjelaskan pengaruh knowlegde management terhadap sustainable livelihood di Kelurahan Bungkutoko Kota Kendari. Populasi dalam penelitian ini adalah masyarakat dan stakeholder di Kelurahan Bungkutoko Kota Kendari. Teknik penarikan sampling adalah secara probability sampling dengan metode pengumpulan data melalui kuesioner, Focus Group Discussion (FGD) dan wawancara. Adapaun analisis data menggunakan analisis regresi linear sederhana melalui bantuan program SPSS versi 20.0 for windows. Responden yang terlibat antara lain aparat pemerintah kelurahan, tokoh masyarakat, kelompok-kelompok nelayan, kelompok wirausahawan, pelaku program pemberdayaan, kelompok wanita, kelompok peduli dan pemerhati. Hasil yang diperoleh adalah knowledge management memiliki pengaruh positif dan signifikan terhadap sustainable livelihood di Kelurahan Bungkutoko Kota Kendari. Hal ini menunjukkan bahwa tinggi rendahnya sustainable livelihood dipengaruhi oleh knowledge management. Semakin tinggi knowledge management para stakeholder yang ada di Kelurahan Bungkutoko Kota Kendari, maka akan semakin tinggi pula sustainable livelihood yang dicapai.
\end{abstract}

Kata Kunci: Knowledge Management, Sustainable Livelihood, Pemberdayaan Masyarakat

\begin{abstract}
This study aims to examine and explain the influence of knowlegde management on sustainable livelihood in the Bungkutoko Urban Village, Kendari City. The population in this study is the community and stakeholders in the Bungkutoko Urban Village of Kendari City. The sampling technique is using probability sampling with data collection methods through questionnaires, Focus Group Discussion and interviews. As for the data analysis using simple linear regression analysis through the help of SPSS version 20.0 for windows. Respondents involved included village government officials, community leaders, fishermen groups, entrepreneur groups, empowerment program actors, women's groups, caring groups and observers. The results obtained are that knowledge management has a positive and significant influence on sustainable livelihood in the Bungkutoko Urban Village of Kendari City. This shows that the level of sustainable livelihood is influenced by knowledge management. The higher the knowledge management of stakeholders in the Bungkutoko Urban Village of Kendari City, then the higher the sustainable livelihood achieved.
\end{abstract}

Keywords: Knowledge Management, Sustainable Livelihood, Community Development 


\section{PENDAHULUAN}

Pembangunan dalam masyarakat merupakan suatu rangkaian upaya yang dilakukan secara terus menerus untuk mencapai suatu tingkat kehidupan masyarakat yang sejahtera lahir dan batin. Peran serta masyarakat dalam pembangunan sangat diperlukan karena masyarakat bertindak sebagai objek sekaligus subjek pembangunan. Kondisi ini menjadi cikal bakal berkembangnya suatu model pembangunan partisipatif. Pembangunan partisipatif merupakan pendekatan pembangunan yang sesuai dengan hakikat otonomi daerah yang meletakkan landasan pembangunan yang tumbuh berkembang dari masyarakat, diselenggarakan secara sadar dan mandiri oleh masyarakat dan hasilnya dinikmati oleh seluruh masyarakat [1]. Melalui program-program pembangunan partisipatif tersebut diharapkan semua elemen masyarakat dapat secara bersama-sama berpartisipasi dengan cara mencurahkan pemikiran dan sumber daya yang dimiliki guna memenuhi kebutuhannya sendiri.

Program pemberdayaan masyarakat di Indonesia, melalui program yang berbentuk bantuan langsung masyarakat, merupakan bentuk paradigma program pembangunan dengan mengedepankan partisipasi masyarakat. Pemberdayaan masyarakat adalah upaya untuk menciptakan dan meningkatkan kapasitas masyarakat, baik secara individu maupan berkelompok, dalam memecahkan berbagai persoalan terkait upaya peningkatan kualitas hidup, kemandirian dan kesejahteraannya [2]. Pemberdayaan masyarakat memerlukan keterlibatan yang lebih besar dari perangkat pemerintah daerah serta berbagai pihak untuk memberikan kesempatan dan menjamin keberlanjutan berbagai hasil yang dicapai [3].

Kelurahan Bungkutoko adalah salah satu kelurahan yang berada di kota kendari yang selalu mendapatkan bantuan program baik dari pemerintah maupun swasta untuk mengembangkan potensi yang dimiliki agar tercipta kesejahteraan masyarakat secara luas. Hal ini tentunya memerlukan pengelolaan yang baik agar program tersebut tidaklah mubazir atau sia-sia demi terciptanya keberlanjutan penghidupan yang layak atau sustainable livelihood [4].

Penyebab masyarakat Kelurahan Bungkutoko belum mandiri dalam arti luas dikarenakan masyarakat yang tergabung dalam beberapa stakeholder kurang memahami dengan baik fungsi knowledge management. Knowledge management diartikan sebagai eksploitasi dan pengembangan aset pengetahuan dari sebuah organisasi dengan sebuah pandangan terhadap tujuan organisasi [5]. Mengoptimalkan fungsi knowledge management dapat mengelimininasi konflik kepentingan baik antar pengurus maupun organisasi dengan 
pihak luar [6]. Empat tipe interaksi antara dan diluar sebuah organisasi yang didasarkan pada perbedaan yang jelas antara tacit dan explisit knowledge yaitu sosialisasi, eksternalisasi, kombinasi, dan internalisasi [7]. Dari sisi sosialisasi, stakeholder diperhadapkan pada banyaknya ide baik dari pengurus maupun masyarakat yang harus dikomunikasikan dan disosialisasikan sehingga tercapai dan diterimanya ide tersebut disemua kalangan. Berdasarkan pemaparan latar belakang penelitian dan peninjauan awal pada objek penelitian maka penulis mencoba mengkaji Pengaruh Knowledge Management Terhadap Sustainable Livelihood Di Kelurahan Bungkutoko Kota Kendari.

\section{METODE PENELITIAN}

Desain penelitian ini adalah penelitian survei, yaitu penelitian yang mengambil sampel dari beberapa stakeholder di kelurahan Bungkutoko Kota Kendari dan menggunakan kuesioner sebagai alat pengumpulan data yang utama. Sedangkan berdasarkan tujuannya, penelitian ini bertujuan untuk menguji hubungan pengaruh knowledge management terhadap sustainable livelihood di kelurahan tersebut, maka penelitian ini dikategorikan penelitian penjelasan atau explanatory research, yaitu penelitian yang menjelaskan hubungan kausal antara variabelvariabel penelitian melalui pengujian hipotesis [8].

Penelitian ini dilaksanakan di Kelurahan Bungkutoko dengan melibatkan beberapa stakeholder yakni aparat pemerintah kelurahan, tokoh masyarakat, kelompok nelayan, kelompok wirausahawan, pelaku program pemberdayaan, kelompok wanita, dan kelompok peduli serta pemerhati dengan durasi waktu penelitian selama 2 bulan. Adapun teknik pengumpulan data yang digunakan dalam penelitian ini terdiri dari a) Kuesioner, dilakukan dengan menyebar pertanyaan kepada responden. Kuesioner ini juga dilengkapi dengan kolom alasan pemilihan jawaban dengan tujuan untuk menggali informasi lebih dalam dari responden, alasan pemilihan jawaban ini akan sangat berguna sebagai pelengkap pembahasan hasil analisis data; b) Focus Grup Discusion, dilakukan terhadap beberapa kelompok guna menemukan dan memahami beberapa masalah serta adanya harapan bersama terhadap solusi permasalahan di lapangan; dan c) Wawancara, dilakukan dengan menghubungi beberapa responden yaitu stakeholder di Kelurahan Bungkutoko dengan mengajukan beberapa pertanyaan yang dapat menguatkan hasil kuesioner.

Analisis data yang digunakan adalah analisis regresi linier sederhana (simple linier regression). Secara teoritis model regresi tersebut akan menghasilkan nilai parameter model 
praduga yang sahih dan BLUE (Best Linier Unbiased Estimation) bila dipenuhi uji asumsi klasik [9]. Analisis regresi linier sederhana digunakan untuk mengetahui pengaruh variabel knowledge management terhadap variabel sustainable livelihood di Kelurahan Bungkutoko Kota Kendari. Persamaan regresi tersebut adalah sebagai berikut:

$$
\mathbf{Y}=\alpha+\beta_{1} \mathbf{X}_{1}+\varepsilon
$$

Keterangan:

$$
\begin{array}{ll}
\mathrm{Y} & =\text { Variabel Sustainable Livelihood } \\
\alpha & =\text { Konstanta } \\
\beta_{1} & =\text { Koefisien regresi untuk Knowledge Management } \\
\mathrm{X}_{1} & =\text { Variabel Knowledge Management } \\
\varepsilon & =\text { Error }
\end{array}
$$

Hipotesis penelitian yang akan diuji dirumuskan secara statistik sebagai berikut:

$\mathrm{H}_{\mathrm{a}}: \mathrm{rxy} \neq 0$ tidak ada pengaruh positif dan signifikan antara variabel knowledge management dengan variabel sustainable livelihood

$\mathrm{H}_{\mathrm{o}}$ : rxy $=0$ ada pengaruh positif dan signifikan antara variabel knowledge management dengan variabel sustainable livelihood

Kaidah keputusan:

1. Jika nilai probabilitas 0,05 lebih kecil atau sama dengan nilai probabilitas Sig atau $(0,05 \leq \mathrm{Sig})$. maka Ho diterima dan Ha ditolak, artinya tidak signifikan.

Jika nilai probabilitas 0,05 lebih besar atau sama dengan nilai probabilitas Sig atau $(0,05 \geq \mathrm{Sig})$. maka Ho ditolak dan Ha diterima, artinya signifikan.

\section{HASIL DAN PEMBAHASAN}

\subsection{Pengujian Asumsi Klasik}

\section{a) Uji Normalitas Data}

Salah satu syarat yang harus dipenuhi dalam analisis regresi adalah data dan model regresi berdistribusi normal. Kenormalan data dapat dilihat dari uji normalitas Kolmogorov-Smirnof dari masing-masing variabel [10]. Data dari analisis dengan bantuan komputer program SPSS versi 20.0 For Windows. Dasar pengambilan keputusan berdasarkan probabilitas. Jika probabilitas > 0,05 maka data penelitian berdistribusi normal. 
Tabel 1. Hasil Uji Normalitas Data

\begin{tabular}{llcc}
\hline & & $\begin{array}{c}\text { Sustainable } \\
\text { Livelihood }\end{array}$ & Knowledge Management \\
\hline $\mathrm{N}$ & Mean & 33 & 33 \\
Normal & 38.697 & 103.6364 \\
Parameters & a,b & 5.97121 & 15.86824 \\
& Std. Deviation & 0.135 & 0.095 \\
Most Extreme & Absolute & 0.085 & 0.069 \\
Differences & Positive & -0.135 & -0.095 \\
\multirow{2}{*}{ Kolmogorov-Smirnov Z } & 0.775 & 0.545 \\
Asymp. Sig. (2-tailed) & 0.585 & 0.928 \\
\hline
\end{tabular}

a. Test distribution is Normal.

b. Calculated from data.

Sumber: Data diolah, 2019

Hasil uji normalitas menggunakan Kolmogorov Smirnov terlihat Sig untuk dua sisi diperoleh nilai signifikansi variabel sustainable livelihood sebesar 0,585 dan variabel knowledge management sebesar 0,928. Nilai signifikansi dari masing-masing variabel > 0,05. yang berarti bahwa $\mathrm{H}_{0}$ diterima atau data dari masing-masing variabel berdistribusi normal.

Dengan demikian berdasarkan hasil uji normalitas di atas menunjukan bahwa kedua variabel dalam penelitian ini baik variabel knowledge management (X) maupun variabel sustainable livelihood $(\mathrm{Y})$ memiliki distribusi data yang normal. Dengan demikian dapat dikatakan bahwa data dalam penelitian ini dapat mewakili populasi sehingga hasil analisis dan kesimpulan data dalam penelitian dapat digeneralisasikan terhadap populasi penelitian.

\section{b) Uji Linearitas}

Uji linieritas dapat di lihat dari nilai signifikansi pada deviation of linierity untuk $\mathrm{X}$ terhadap Y. Apabila nilai signifikansi > 0,05. dapat disimpulkan bahwa hubungannya bersifat linier. Lebih jelasnya hasil pengujian linieritas ini dapat diuraikan sebagai berikut: 
Tabel 2. Hasil Uji ANOVA

\begin{tabular}{|c|c|c|c|c|c|c|c|}
\hline & & & $\begin{array}{c}\text { Sum of } \\
\text { Squares }\end{array}$ & $D f$ & $\begin{array}{c}\text { Mean } \\
\text { Square }\end{array}$ & $F$ & Sig. \\
\hline & & (Combined) & 982.303 & 22 & 44.65 & 2.814 & 0.047 \\
\hline & & Linearity & 560.607 & 1 & 560.607 & 35.332 & 0 \\
\hline \multirow{3}{*}{$\begin{array}{l}\text { Sustainable } \\
\text { Livelihood } * \\
\text { Knowledge } \\
\text { Management }\end{array}$} & $\begin{array}{l}\text { Between } \\
\text { Groups }\end{array}$ & $\begin{array}{l}\text { Deviation from } \\
\text { Linearity }\end{array}$ & 421.696 & 21 & \multirow{3}{*}{$\begin{array}{l}20.081 \\
15.867\end{array}$} & \multirow{3}{*}{1.266} & \multirow{3}{*}{0.36} \\
\hline & \multicolumn{2}{|c|}{ Within Groups } & 158.667 & 10 & & & \\
\hline & \multicolumn{2}{|l|}{ Total } & 1140.97 & 32 & & & \\
\hline
\end{tabular}

Tabel 2 menunjukkan nilai signifikansi dari masing-masing pengujian yaitu 0,361 $>$ 0,05 yang berarti bahwa pengaruh antara knowledge management dengan sustainable livelihood bersifat linier.

\subsection{Pengujian Hipotesis}

\section{a) Uji Korelasi}

Untuk mengetahui kekuatan hubungan (korelasi) antara knowledge management dengan sustainable livelihood dilakukan melalui analisis korelasi dengan menggunakan analisis korelasi Product Moment Pearson. Adapun hasil pengujian koefisien korelasi dapat dilihat pada tabel di bawah ini.

\section{Tabel 3. Hasil Uji Korelasi}

\section{Correlations}

\begin{tabular}{llcc} 
& Pearson Correlation & 1 & $.674^{* * *}$ \\
Knowledge & Sig. (2-tailed) & & 0,00 \\
Management & $\mathrm{N}$ & 33 & 33 \\
& Pearson Correlation & $.674^{* *}$ & 1 \\
Sustainable & Sig. (2-tailed) & 0,00 & \\
Livelihood & $\mathrm{N}$ & 33 & 33 \\
\hline **. Correlation is significant at the 0.01 level (2-tailed). & \\
Sumber: Data diolah, 2019
\end{tabular}


Berdasarkan Tabel 3 di atas menunjukan nilai probabilitas 0,00 dimana lebih kecil 0,05 maka dapat disimpulkan bahwa terdapat korelasi yang positif dan signifikan antara knowledge management dengan sustainable livelihood, sedangkan nilai korelasi $\mathrm{r}$ $=0,674$ dimaknai bahwa setiap ada evaluasi knowledge management sebesar $1 \%$ maka sustainable livelihood juga bertambah sebesar 0,674. Selain itu, Tabel 3 di atas menunjukan bahwa nilai korelasi variabel knowledge management (X) terhadap sustainable livelihood $(\mathrm{Y})$ sebesar 0,674 menunjukkan bahwa tedapat hubungan yang kuat antara knowledge management dengan sustainable livelihood.

Pembuktian hipotesis terdapat hubungan positif dan signifikan antara knowledge management dengan sustainable livelihood dilakukan melalui uji signifikan antara knowledge management dengan sustainable livelihood yang ditunjukan oleh Tabel 3. Variabel knowledge management dengan sustainable livelihood dengan metode dua sisi (Sig.(2-tailed)) dari output nilai Sig. sebesar 0,000 < 0,05, maka Ho ditolak dan Ha diterima. Hal ini dimaknai bahwa knowledge management mempunyai hubungan positif dan signifikan dengan sustainable livelihood.

\section{b) Uji Regresi}

Untuk mengetahui bentuk hubungan kedua variabel dilakukan uji regresi. Berdasarkan perhitungan analisis regresi linier yang dilakukan melalui analisa statistik dengan mengunakan program SPSS 20.0 for windows, hasil analisis tersebut dapat divisualisasikan pada tabel di bawah ini:

Tabe 4. Hasil Uji ANOVA

\begin{tabular}{|c|c|c|c|c|c|c|}
\hline \multicolumn{2}{|l|}{ Model } & Sum of Squares & $D f$ & Mean Square & $F$ & Sig. \\
\hline & Regression & 564.978 & 1 & 564.978 & 25.807 & $.000^{\mathrm{b}}$ \\
\hline & Residual & 678.658 & 31 & 21.892 & & \\
\hline 1 & Total & 1243.636 & 32 & & & \\
\hline
\end{tabular}

a. Dependent Variable: Sustainable Livelihood

b. Predictors: (Constant), Knowledge Management

Sumber: Data diolah, 2019

Tabel 4 diatas menunjukkan hasil yang diperoleh adalah nilai $F_{\text {hitung }}=16,61$ dengan tingkat profitabilitas sig. 0,000. Oleh karena tingkat profitabilitas 0,000 jauh 
lebih kecil dari $0,005(0,000<0,005)$, hal ini berarti model regresi yang diperoleh signifikan dan dapat digunakan untuk menaksir sustainable livelihood (Y) apabila knowledge management (X) diketahui. Dengan kata lain variabel (Y) sustainable livelihood dipengaruhi oleh variabel bebas $(\mathrm{X})$ dan yaitu knowledge management.

Tabel 5. Hasil Uji Coefficients

\begin{tabular}{|c|c|c|c|c|c|c|}
\hline & \multirow[t]{2}{*}{ Model } & \multicolumn{2}{|c|}{$\begin{array}{c}\text { Unstandardized } \\
\text { Coefficients }\end{array}$} & \multirow{2}{*}{$\begin{array}{c}\text { Standardized } \\
\text { Coefficients } \\
\text { Beta } \\
\end{array}$} & \multirow[t]{2}{*}{$t$} & \multirow[t]{2}{*}{ Sig. } \\
\hline & & $\beta$ & Std. Error & & & \\
\hline \multirow[b]{2}{*}{1} & (Constant) & 6.877 & 6.447 & & 1.067 & 0.294 \\
\hline & $\begin{array}{l}\text { Knowledge } \\
\text { Management }\end{array}$ & 0.302 & 0.059 & 0.674 & 5.08 & 0,00 \\
\hline
\end{tabular}

Tabel 5 menjelaskan bahwa hasil pengujian regresi mengenai pengaruh antara variabel knowledge management (X) dengan variabel sustainable livelihood (Y) diperoleh nilai $\beta=0,302$ dengan probabilitas 0,00 , begitu juga nilai $\mathrm{t}_{\text {hitung }}=5,08>\mathrm{t}_{\text {table }}=$ 1,70 maka disimpulkan bahwa bentuk pengaruh kedua variabel adalah positif dengan persamaan $\hat{Y}=6,877+0,302 X$. Nilai $\beta=0,302$ artinya bahwa bilamana tidak ada knowledge management, maka sustainable livelihood berada pada konstanta 6,877 sedangkan nilai koefisien regresi 0,302 dimaknai bahwa setiap ada upaya penerapan knowledge management maka sustainable livelihood akan bertambah sebesar 0,302 atau $30,2 \%$.

\subsection{Keofisien Korelasi dan Koefisien Determinasi}

Pengujian ini dilakukan untuk mengetahui seberapa besar hubungan variabel independen yang digunakan dalam penelitian, yaitu knowledge management terhadap sustainable livelihood.

Tabel 6. Model Summary

\begin{tabular}{|c|c|c|c|c|c|c|c|c|c|}
\hline \multirow[t]{2}{*}{ Model } & \multirow[t]{2}{*}{$R$} & \multirow{2}{*}{$\begin{array}{c}R \\
\text { Square }\end{array}$} & \multirow{2}{*}{$\begin{array}{c}\text { Adjusted } R \\
\text { Square }\end{array}$} & \multirow{2}{*}{$\begin{array}{c}\text { Std. Error } \\
\text { of the } \\
\text { Estimate }\end{array}$} & \multicolumn{5}{|c|}{ Change Statistics } \\
\hline & & & & & $\begin{array}{c}R \text { Square } \\
\text { Change }\end{array}$ & $\begin{array}{c}F \\
\text { Change }\end{array}$ & $d f 1$ & $d f 2$ & $\begin{array}{c}\text { Sig. F } \\
\text { Change }\end{array}$ \\
\hline 1 & $.674^{\mathrm{a}}$ & 0.454 & 0.437 & 4.67891 & 0.454 & 25.807 & 1 & 31 & 0,00 \\
\hline
\end{tabular}

Sumber: Data diolah, 2019 
Berdasarkan tabel 6 di atas, dinyatakan bahwa besarnya hubungan antara knowledge management dengan sustainable livelihood dihitung dengan koefisien korelasi adalah 0,674 $\left(\mathrm{R}_{\mathrm{xy}}=0,674\right)$. Sedangkan kontribusi variabel knowledge management terhadap sustainable livelihood adalah $\left(\mathrm{R}^{2}\right)=45,4 \%$, dimaknai bahwa $45,4 \%$ sustainable livelihood dapat dijelaskan oleh knowledge management sedangkan sisanya dijelaskan oleh variabel lain yang tidak diteliti.

\section{KESIMPULAN}

Berdasarkan hasil analisis dan pembahasan dalam penelitian ini, dapat disimpulkan bahwa knowledge management memiliki pengaruh positif dan signifikan terhadap sustainable livelihood di Kelurahan Bungkutoko Kota Kendari. Hal ini menunjukkan bahwa tinggi rendahnya sustainable livelihood dipengaruhi oleh knowledge management. Semakin baik knowledge management para stakeholder yang ada di Kelurahan Bungkutoko Kota Kendari, maka akan semakin baik pula sustainable livelihood yang ingin dicapai.

\section{SARAN}

Strategi yang direkomendasikan dalam rangka mewujudkan penghidupan berkelanjutan di Kelurahan Bungkutuko Kota Kendari melalui peningkatan keterampilan usaha masyarakat berbasis potensi unggulan lokal, penumbuhan kembali kesadaran dan modal sosial masyarakat untuk berperilaku ramah lingkungan, pembentukan dan pengembangan Kelompok Swadaya Masyarakat mengenai air bersih, pengembangan agrowisata berbasis masyarakat, pengembangan sentra industri, pembentukan kelompok ternak dan sosialisasi serta penerapan peraturan lingkungan hidup terhadap masyarakat.

\section{DAFTAR PUSTAKA}

[1] Sumaryadi, I Nyoman. 2005. Perencanaan Pembangunan Daerah Otonom dan Pemberdayaan Masyarakat. Jakarta: Citra Utama.

[2] Pokja Pengendali Penanggulangan Kemiskinan Berbasis Pemberdayaan Masyarakat-PNPM Mandiri. 2010. Tentang PNPM. P3KBPMPNPM MP.

[3] Direktorat Jenderal Pemberdayaan Masyarakat dan Desa. 2008. Penjelasan Petunjuk Teknis Operasional Program Nasional Pemberdayaan (PNPM) Mandiri Perdesaan. Jakarta. 
[4] Haidar. 2009. Sustainable Livelihod Approach: The Framework, Lessons Learnt from Practice and Policy Recommendations.

[5] Bhatt, G.D. 2000. Organizing Knowledge In The Knowledge Development Cycle. Journal of Knowledge Management, 4(1), 15-26.

[6] Kosasih N. dan Budiani S. 2007. Pengaruh Knowledge Management terhadap Kinerja Karyawan: Studi Kasus Departemen Front Office Surabaya Plaza Hotel. Jurnal Manajemen Perhotelan, Vol.3, No.2, September: 80-88.

[7] Takeuchi, H \& Nonaka, I. 2004. Hitotsubashi on Knowledge Management. Singapore: John Wiley.

[8] Sugiyono. 2010. Metode Penelitian Kuantitatif Kualitatif Dan R\&D. CV Bandung: Alfabeta.

[9] Sekaran, Uma. 2011. Research Methods for Business: A Skill-Building Approach. $4^{\text {th }}$ Edition. Jakarta: Salemba Empat.

[10] Umar, Husein. 2008. Metodologi Penelitian Untuk Skripsi dan Tesis Bisnis. Jakarta: PT.Raya Grafindo Persada. 